\title{
Persepsi Petani Lada terhadap Diseminasi Teknologi Usahatani Lada di Bangka Belitung
}

\section{Perception of Farmer's Pepper to The Dissemination of Pepper Farming Technology in Bangka Belitung}

\author{
Minas Tiurlina Panggabean ${ }^{1}$, Siti Amanah², Prabowo Tjitropranoto ${ }^{2}$ \\ ${ }^{1}$ Balai Pengkajian Teknologi Pertanian Kepulauan Bangka Belitung, Pangkalpinang \\ ${ }^{2}$ Departemen Sains Komunikasi dan Pengembangan Masyarakat, Fakultas Ekologi Manusia, \\ Institut Pertanian Bogor, Bogor
}

\begin{abstract}
The technology used is traditional and resulting in low production and productivity of pepper and different from optimal potential. To increase pepper productivity is by adopting inovative technology generated by research institutions. The dissemination technique of inovative technology should be able to encourage farmers in adopting the technology. The study aimed to analyze the perception of farmers on pepper dissemination techniques and the factors that influence the adoption of pepper farming technology, done at three villages : Serdang, Delas and Nyelanding South Bangka Regency in March until May 2015. The study design using method survey. The total sample of this research is 90 people. The analytical method used is descriptive and regression analysis. The results show that the farmers perceive open field, demonstration plot and display as good dissemination techniques. The adoption of technology influenced by display technique were farmers age, farmers experience and exhibition.
\end{abstract}

Keywords: perception, pepper farmer, dissemination, pepper farming innovation

\begin{abstract}
Abstrak
Usahatani lada yang dilaksanakan oleh masyarakat Bangka Selatan masih menggunakan teknologi tradisional sehingga produksi dan produktivitas lada relatif rendah dan jauh dari potensi optimalnya. Usaha meningkatkan produktifitas dan nilai tambah di tingkat petani pedesaan adalah dengan menerapkan inovasi teknologi yang dihasilkan oleh lembaga penelitian. Penyebarluasan teknologi baru memerlukan teknik diseminasi yang dapat meyakinkan penggunanya. Persepsi petani terhadap teknik diseminasi yang menentukan keyakinan petani terhadap teknologi inovatif yang didiseminasikan. Penelitian ini bertujuan untuk menganalisis persepsi petani lada terhadap teknik diseminasi teknologi usahatani lada dan faktor-faktor yang berpengaruh terhadap adopsi teknologi usahatani lada. Penelitian dilaksanakan di tiga desa yaitu Desa Serdang, Desa Delas dan Desa Nyelanding Kabupaten Bangka Selatan dan pengumpulan data dilakukan pada bulan Maret sampai dengan Mei 2015. Penelitian menggunakan disain survey. Jumlah sampel penelitian ini adalah 90 orang. Metode analisis yang digunakan adalah deskriptif dan regresi. Hasil penelitian menunjukkan bahwa persepsi petani terhadap teknik diseminasi teknologi usahatani lada yang baik adalah melalui temu lapang demonstrasi plot dan pameran. Tingkat adopsi inovasi usahatani lada dipengaruhi umur dan lama berusahatani dan pameran.
\end{abstract}

Kata kunci: persepsi, petani lada, diseminasi, usahatani lada

\section{Pendahuluan}

Provinsi Kepulauan Bangka Selatan merupakan provinsi yang terletak di sebelah timur Provinsi Sumatera Selatan berupa gugusan pulau-pulau dengan Pulau Bangka dan Pulau Belitung sebagai pulau paling besar. Bangka Belitung memiliki potensi lahan perkebunan berupa lahan kering dataran rendah tanah masam dan tingkat kesuburan yang rendah. Secara umum jenis tanah di Bangka adalah podsolik, yang miskin akan unsur-unsur hara dan kondisi fisik tanahnya kurang baik untuk

Korespondensi Penulis

E-mail:minas_tiurlina@yahoo.co.id diusahakan sebagai lahan perkebunan.

Tanaman lada merupakan komoditas andalan bagi masyarakat Bangka Belitung. Tanaman lada Bangka Belitung memiliki kekuatan dan daya jual tersendiri karena cita rasanya yang khas. Lada Indonesia di kenal dengan nama Muntok white pepper untuk sebutan bagi lada putih. Lada memiliki peran penting dalam perekonomian nasional sebagai tumpuan hidup bagi 327.061 Kepala Keluarga Tani Indonesia (Irianto, 2009). Lada berperan sebagai penggerak perekonomian di sentra-sentra produksi dan sumber pendapatan sebanyak 46.620 petani lada 
tahun 2013 di Bangka Belitung (Aprionis, 2015).

Tanaman lada diusahakan dalam bentuk perkebunan rakyat dengan pengelolaan yang tradisional sehingga produktivitasnya rendah. Luas pertanaman dan produksi lada di Provinsi Kepulauan Bangka Belitung semakin menurun. Luas pertanaman kebun lada 63.956,79 Ha pada tahun 2002 menjadi 37.040 Ha pada tahun 2009 atau berkurang sekitar 57,9 persen selama periode 20022009. Produksi lada terus menurun dari 33.000 ton tahun 2002 menjadi 15.601 ton pada tahun 2009 dan terjadi penurunan 42,28 persen dengan produktivitas berkisar $0,8 \mathrm{~kg} /$ tanaman. Ada beberapa faktor yang mempengaruhi penurunan tersebut antara lain 1) kegiatan penambangan timah rakyat (tambang inkonvensional) yang lebih menjanjikan, 2) harga lada yang kurang menguntungkan karena biaya produksi tinggi, 3) serangan penyakit yang sulit diatasi oleh petani dan harga saprodi seperti pupuk kimia mahal, 4) penggunaan teknologi belum sesuai dengan teknologi anjuran (BPTP Kepulauan Bangka Belitung, 2011).

Menurut Irawati et al., (2009) melalui penerapan teknologi usahatani lada ramah lingkungan, produksi lada dapat ditingkatkan menjadi 3,75 ton per ha dibandingkan dengan teknologi konvensional sebanyak 1,80 ton per ha. Untuk meningkatkan produktifitas dan nilai tambah di tingkat petani pedesaan adalah dengan menerapkan inovasi teknologi yang dihasilkan oleh lembaga penelitian. Teknologi hasil penelitian untuk mengatasi permasalahan teknis penurunan produksi lada sudah tersedia seperti penggunaan beberapa varietas unggul lada yang telah di lepas, teknologi lada ramah lingkungan, pengembangan kelembagaan perbenihan lada, namun dalam pelaksanaannya dilapangan tidak berjalan secara optimal (Hermawan et al., 2009).

Pemanfaatan teknologi belum dilakukan secara optimal dalam meningkatkan daya saing komoditas pertanian. Hal ini ditunjukkan oleh banyaknya petani yang belum tahu atau tidak menerapkan inovasi teknologi hasil penelitian. Menurut Paryono et al., (2001) bahwa faktor penyebabnya antara lain adalah a) inovasi tidak sampai kepada petani, b) inovasi tidak sesuai dengan kebutuhan petani, c) inovasi belum dipahami dan diyakini petani, d) kesulitan memperoleh sarana produksi anjuran, dan e) keterbatasan modal petani. Sehubungan dengan hal tersebut maka sebelum suatu inovasi teknologi diadopsi oleh pengguna, terdapat fase-fase kegiatan yang dilakukan oleh seseorang sejak mengenal inovasi, menaruh minat, menilai sampai menerapkan teknologi. Banyak faktor yang dipertimbangkan oleh petani untuk dapat menerima atau menolak sebuah inovasi teknologi uahatani lada. Proses keputusan inovasi merupakan suatu proses mental sejak seseorang mulai pertama sekali mengetahui adanya suatu inovasi, membentuk sikap terhadap inovasi tersebut, mengambil keputusan untuk mengadopsi atau menolak, mengimplementasikan ide-ide baru dan membuat konfirmasi atas keputusan ide tersebut. Proses ini terdiri atas rangkaian pilihan dan tindakan individu dari waktu ke waktu atau suatu sistem evaluasi ide baru dan memutuskan mempraktekkan inovasi atau menolaknya. Perilaku ketidakpastian dalam memutuskan tentang suatu alternatif baru ini terkait dengan ide yang telah ada sebelumnya. Sifat suatu inovasi dan ketidakpastian berhubungan dengan sifat tersebut yang merupakan aspek khusus dari pengambilan keputusan inovasi (Rogers, 2003).

Petani sebagai pelaku utama usaha pertanian sehingga sikap, pengetahuan, prilaku dan keterampilan petani harus terus ditingkatkan agar mampu melakukan usaha taninya dengan orientasi bisnis. Proses pemahaman dan pengenalan terhadap inovasi baru bagi petani dipengaruhi oleh berbagai faktor antara lain : sumber daya yang dimiliki, kebijakan pemerintah, kegiatan penyuluhan dan karakteristik petani. Guna mendukung percepatan adopsi inovasi diperlukan informasi tentang persepsi petani terhadap inovasi tersebut. Semakin tinggi derajat kesamaan persepsi antar komunikan dengan pengguna, maka akan mempermudah proses komunikasi, karena persepsi merupakan inti dari komunikasi (Mulyana, 2000).

Berpijak dari kerangka pemikiran tersebut, maka penelitian ini berusaha menjawab pertanyaan penelitian sebagai berikut: bagaimana persepsi petani lada terhadap teknik diseminasi teknologi usahatani lada dan faktor-faktor apa saja yang berpengaruh terhadap tingkat adopsi usahatani lada. Berdasarkan rumusan masalah penelitian, maka tujuan penelitian ini adalah menganalisis persepsi petani lada terhadap teknik diseminasi teknologi usahatani lada dan menganalisis faktor-faktor yang 
berpengaruh terhadap tingkat adopsi usahatani lada.

\section{Metode Penelitian}

Penelitian tentang persepsi petani lada terhadap diseminasi teknologi usahatani lada ini menggunakan acuan teori yang dikemukakan Rogers (2003) tentang pengambilan keputusan inovasi. Variabel yang digunakan terdiri dari: 1) variabel independent yaitu karakteristik petani (umur, pendidikan formal, jumlah tanggungan keluarga, lama usahatani, luas lahan, kekosmopolitan dan pendapatan) dan teknik diseminasi teknologi usahatani lada (temu lapang, demonstrasi plot, visitor plot dan pameran) dan 2) variabel dependent yaitu tingkat adopsi teknologi usahatani lada (varietas unggul, pemupukan, penggunaan bahan organik, pengendalian hama dan penyakit menggunakan agensia hayati, penggunaan tiang panjat hidup dan penanganan panen dan pascapanen).

Penelitian dilakukan menggunakan metode survei, yang bersifat eksplanasi yakni menjelaskan fenomena perilaku petani yang terjadi dalam tahapan proses keputusan inovasi. Unit analisis dalam penelitian ini adalah petani sebagai responden penelitian. Populasi penelitian ini adalah petani yang berada di lokasi penelitian Desa Serdang Kecamatan Toboali, Desa Delas dan Desa Nyelanding Kecamatan Air Gegas, Kabupaten Bangka Selatan Provinsi Kepulauan Bangka Belitung. Penentuan jumlah sampel petani menggunakan rumus Slovin (Sevilla et al., 1993) dengan jumlah sampel sebanyak 90 petani responden. Pengambilan sampel petani dilakukan dengan sampel acak sederhana (simple random sampling). Pengumpulan data dilakukan pada bulan Maret sampai Mei 2015.

Berdasarkan sumber data, maka data dalam penelitian ini bersumber pada sumber primer dan sekunder. Data primer diperoleh secara langsung dari sumbernya, yakni petani responden. Data primer dikumpulkan melalui wawancara, dengan menggunakan kuisioner yang telah memenuhi persyaratan kesahihan (validitas), keterandalan (reliabilitas) dan dapat dipertanggungjawabkan (Kerlinger, 2000; Nawawi dan Hadari, 2006). Uji Validitas instrumen yang digunakan adalah validitas konstruk. Berdasarkan hasil uji statistik yang dilakukan, maka diperoleh hasil yang valid dengan kisaran korelasi 0,420 sampai 0,839. Hasil uji instrumen penelitian dinyatakan reliabel apabila nilai koefisien alpha Cronbach $(0,61-0,80)$. Apabila koefisien alpha Cronbach lebih rendah maka penyataan dan pertanyaan dalam kuisioner diperbaiki. Oleh karena itu, maka instrument penelitian ini bisa dipergunakan.

Data yang dikumpulkan dalam penelitian ini adalah data primer dan data sekunder. Data primer diperoleh melalui: (1) pengamatan (observation), yaitu data dikumpulkan melalui pengamatan secara langsung fenomena yang terjadi di lokasi penelitian; (2) kuesioner (questioner), yaitu daftar pertanyaan tertulis yang berhubungan dengan variabel-variabel penelitianyang dikaji dalampenelitian. Datasekunder dalam penelitian ini dikumpulkan dari dokumentasi (documentation), yaitu mengumpulkan data dengan cara penelusuran dan pencatatan data, dokumen, arsip, peraturan-peraturan maupun referensi yang relevan di instansi yang ada kaitannya dengan penelitian. Sumber-sumber tersebut antara lain adalah dokumen-dokumen dan pustaka dari Dinas Perkebunan dan Kehutanan Kabupaten Bangka Selatan, Balai Pengkajian Teknologi Pertanian (BPTP), Badan Pelaksana Penyuluhan Pertanian dan Ketahanan Pangan Kabupaten Bangka Selatan, Badan Pusat Statistik (BPS) Provinsi Bangka Belitung dan Badan Pengelolaan Pengembangan dan Pemasaran Lada (BP3L) Provinsi Kepulauan Bangka Belitung, tokoh masyarakat, dan penyuluh pertanian lapangan sebagai data dukung.

Analisis data mencakup: 1) analisis data deskriptif, dan 2) analisis data inferensial. Analisis data deskriptif berupa distribusi frekuensi sedangkan analisis statistik inferensial meliputi regresi linear berganda menggunakan program Microsoft excel dan software SPSS. Syarat data untuk melakukan uji statistik regresi linear berganda adalah data dengan skala rasio atau skala interval. Oleh sebab itu data ordinal yang diperoleh perlu dilakukan transformasi data telebih dahulu ke dalam bentuk indeks. Berdasarkan jumlah nilai indeks, maka dilakukan pengklasifikasian selanjutnya. Setiap indikator yang ada memiliki nilai $0-100$. Jumlah skor terendah merupakan nilai indeks indikator terkecil sedangkan nilai 100 merupakan jumlah indeks maksimum, rumus yang digunakan dalam transformasi data adalah: 
Indeks Transformasi $=$

Jumlah skor yang diperoleh per indikator - jumlah skor terkecil

Jumlah skor maksimum - jumlah skor terkecil

\section{Hasil dan Pembahasan}

\section{Gambaran wilayah penelitian}

Secara administratif wilayah Kabupaten Bangka Selatan berbatasan sebelah utara dengan Kabupaten Bangka Tengah, sebelah selatan dengan Selat Bangka dan Laut Jawa, sebelah timur dengan Selat Gaspar dan sebelah barat dengan Selat Bangka. Jumlah penduduk Kabupaten Bangka Selatan pada tahun 2013 sebesar 185.514 jiwa, dengan tingkat kepadatan penduduk sebesar 51 orang per Km2. Jumlah penduduk laki-laki pada tahun 2013 sebanyak 96.229 jiwa dan penduduk perempuan sebanyak 89.285 jiwa. Rasio jenis kelamin tahun yang sama sebesar 1.08, artinya pada tahun 2013 untuk setiap 208 penduduk di Kabupaten Bangka Selatan terdapat 100 penduduk perempuan dan 108 penduduk laki-laki.

Sektor pertanian saat ini masih memiliki peranan strategis, yakni sebagai sumber utama kehidupan dan pendapatan masyarakat petani, sebagai penghasil pangan bagi masyarakat, sebagai penghasil bahan mentah dan bahan baku bagi industri pengolahan, sebagai penyedia lapangan pekerjaan dan lapangan usaha yang menjadi sumber penghasilan masyarakat. Pembangunan pertanian meliputi pertanian tanaman pangan, hortikultura, perkebunan, kehutanan, perternakan dan perikanan.

\section{Karakteristik Petani Lada}

Karakteristik individu merupakan perbedaan antara individu yang satu dengan individu yang lainnya. Memahami karakteristik individu sangat penting, mengingat bahwa setiap individu saling berinteraksi dalam tatanan sosial yang ada di lingkungan masyarakat. Karakteristik petani dalam penelitian ini meliputi umur, pendidikan formal, jumlah tanggungan keluarga, lama berusahatani, luas lahan, kekosmopolitan dan pendapatan. Sebaran responden berdasarkan karakteristik petani lada dapat di lihat pada Tabel 1.

Hasil penelitian memberikan gambaran bahwa sebagian besar petani responden $(65,56 \%)$ terdistribusi pada kategori dewasa yaitu antara 35-52 tahun. Persentase petani berumur tua $(>52$ tahun) relatif sedikit $(18,88 \%)$. Batasan usia kerja menurut Badan Pusat Statistik (2009) berada pada kisaran 15-64 tahun dan digolongkan sebagai umur produktif artinya bahwa secara fisik petani lada mampu untuk melaksanakan usahatani. Hal ini menunjukkan bahwa petani yang usia produktif memiliki kemampuan bekerja dan berpikir yang lebih tinggi dibandingkan dengan petani yang sudah tua. Sejalan dengan pendapat Soekartawi (1988) bahwa umur mempengaruhi kemampuan kerja fisik dan kematangan psikologisnya di mana petani yang berumur muda mempunyai daya kerja fisik yang kuat namun tidak dibarengi dengan kematangn psikologisnya, hal ini yang sering membuat keputusan gegabah yang kadang merugikan dirinya sendiri. Petani berumur muda hingga petani dewasa cenderung tinggi tingkat adopsi inovasinya, karena kekuatan fisik dan kematangan psikologisnya saling mendukung. Sebaliknya jika petani berumur tua cenderung kurang inovatif.

Pendidikan merupakan salah satu indikator utama pembangunan dan kualitas sumber daya manusia. Pendidikan formal sangat penting sebagai modal petani untuk melakukan aktivitasnya karena pendidikan dapat meningkatkan pengalaman dan pengetahuan. Tingkat pendidikan formal petani lada dalam penelitian ini sangat bervariasi, mulai dari Sekolah Dasar (SD) hingga perguruan tinggi. Sebagian besar petani responden $(98,89 \%)$ memiliki pendidikan formal tamat sekolah dasar hingga sekolah menengah. Menurut Soekartawi (1988) secara umum petani yang berpendidikan tinggi relatif lebih cepat dalam melaksanakan adopsi teknologi. Sebaliknya mereka yang berpendidikan rendah agak sulit untuk melaksanakan adopsi inovasi dengan cepat. Roger dan Shoemaker (1971) mengemukakan bahwa umumnya orang yang cepat berhenti dari penggunaan inovasi salah satunya karena pendidikan kurang. Tingkat pendidikan formal petani yang rendah berdampak pada keterbatasan pengetahuan (Hardjanto 2003), implikasi berikutnya dapat mengurangi tingkat respon petani terhadap usaha 
Tabel 1 Sebaran responden berdasarkan karakteristik petani lada di Kabupaten Bangka Selatan

\begin{tabular}{|c|c|c|c|}
\hline Karakteristik Petani & Kategori & $\begin{array}{l}\text { Jumlah } \\
\text { (orang) } \\
\end{array}$ & $\begin{array}{c}\text { Persentase } \\
(\%) \\
\end{array}$ \\
\hline \multirow[t]{3}{*}{ Umur } & Muda $(<34$ Tahun $)$ & 14 & 15,56 \\
\hline & Dewasa (34-52 tahun) & 59 & 65,56 \\
\hline & Tua $(>52)$ tahun $)$ & 17 & 18,88 \\
\hline \multirow[t]{3}{*}{ Pendidikan Formal } & Rendah (tidak tamat SD-Tamat SD) & 38 & 42,22 \\
\hline & Menengah (tamat SMP-SMA) & 51 & 56,67 \\
\hline & Tinggi (tamat D3-Perguruan Tinggi) & 1 & 1,11 \\
\hline \multirow[t]{3}{*}{ Jumlah Tanggungan keluarga } & Sedikit (2-3 orang) & 37 & 41,11 \\
\hline & Sedang (4-5 orang) & 44 & 48,89 \\
\hline & Banyak (6-7 orang) & 9 & 10,00 \\
\hline \multirow[t]{3}{*}{ Lama Berusahatani } & Sedikit (8-12 tahun) & 8 & 8,89 \\
\hline & Sedang (12-27 tahun) & 48 & 53,33 \\
\hline & Lama ( 28-40 tahun) & 34 & 37,78 \\
\hline \multirow[t]{3}{*}{ Luas Lahan } & Sempit $(<0.5 \mathrm{Ha})$ & 1 & 14,45 \\
\hline & Sedang ( 0.5-3 Ha ) & 85 & 8,11 \\
\hline & Luas $(>3 \mathrm{Ha})$ & 4 & 4,44 \\
\hline \multicolumn{4}{|l|}{ Kekosmopolitan } \\
\hline \multirow[t]{2}{*}{ Keluar Kota } & Tidak pernah & 56 & 62,22 \\
\hline & Pernah & 34 & 37,78 \\
\hline \multirow[t]{2}{*}{ Nonton TV } & Tidak pernah & 2 & 2,22 \\
\hline & Pernah & 88 & 97,78 \\
\hline \multirow[t]{2}{*}{ Membaca koran } & Tidak pernah & 79 & 78,78 \\
\hline & Pernah & 11 & 12,22 \\
\hline Mendapat Informasi & Pernah & 56 & 62,22 \\
\hline \multirow[t]{4}{*}{ Pendapatan } & Rendah $(<30$ jt/tahun $)$ & 34 & 37,78 \\
\hline & Sedang (30-120 jt/tahun) & 64 & 71,11 \\
\hline & Tinggi $(>120 \mathrm{jt} /$ tahun & 20 & 22,22 \\
\hline & & 6 & 6,67 \\
\hline
\end{tabular}

untuk mengembangkan pertanian (Mosher, 1987).

Sebagian besar responden penelitian $(48,89 \%)$ memiliki jumlah tanggungan keluarga berkisar empat sampai lima orang per rumah tangga terdistribusi dalam kategori sedang. Hasil wawancara dengan petani responden mengatakan bahwa anggota keluarga ada yang terlibat dalam usahatani lada dan ada yang tidak terlibat. Jumlah anggota keluarga yang yang terlibat dalam usahatani lada seperti membantu memetik hasil panen lada, merendam lada, menjemur dan penyimpanan.

Menurut Hafsah (2003) bahwa semakin besar jumlah tanggungan keluarga akan berakibat pada rendahnya tingkat konsumsi, menurunkan kemampuan berinvestasi dan meningkatkan motivasi dalam mencari nafkah sebagai wujud tanggungjawab terhadap keluarganya. Hal ini berarti bahwa semakin besar jumlah tanggungan keluarga petani lada maka 
semakin besar pula usaha yang harus dilakukan untuk meningkatkan produktivitas usahatani lada agar dapat memenuhi kebutuhan anggota keluarga. Mayoritas petani responden $(63,33 \%)$ telah berusahatani lada sekitar 12-27 tahun terdistribusi dalam kategori sedang. Hal ini menunjukkan bahwa petani lada telah lama dalam berusahatani lada, hal ini disebabkan karena bertani lada sudah menjadi budaya yang turun temurun dari orang tua kepada anaknya sehingga pola usahatani lada terbentuk dari pengalaman dan pengetahuan yang diterima dari orang tua sehingga usahatani lada masih tradisional. Hal ini didukung dari hasil penelitian Azwar (2003), salah satu faktor yang mempengaruhi sikap petani adalah pengalaman pribadi. Menurut Mubyarto (2002), pengalaman dan kemampuan bertani yang dimiliki seseorang sejak lama dapat menjadi cara hidup dan memberikan keuntungan mereka dalam berusahatani.

Lahan merupakan salah satu faktor produksi penting dalam berusahatani. Luas lahan mempengaruhi petani lada dalam menerapkan teknologi usahatani lada. Kepemilikan lahan petani beragam, kisaran 0,5-3 Ha dan lebih besar dari $3 \mathrm{Ha}$. Sebagian besar petani responden $(94,45 \%)$ memiliki luas lahan sekitar 0,5-3 Ha. Besar kecilnya lahan mempengaruhi pendapatan yang diperoleh dari produk yang dihasilkan. Petani lada yang memiliki luas lahan $>3$ hektar memiliki keterampilan yang lebih baik dan rajin serta lebih cepat menerima inovasi dibandingkan petani yang memiliki lahan lebih sempit. Petani yang memiliki ekonomi bagus, mampu untuk membeli sarana produksi termasuk membayar pekerja untuk mengurus perkebunan dan giat dalam mencari informasi baru untuk meningkatkan usahataninya sehingga usaha mereka lebih maju. Saragih (2001) menjelaskan bahwa luas lahan berhubungan positif dengan tingkat adopsi petani, di mana semakin luas lahan usahatani semakin cepat mengadopsi, karena adanya kemampuan ekonomi lebih. Hasil penelitian Susi dan Evi (2010), menunjukkan bahwa petani yang memiliki lahan yang lebih luas (1-6 Ha) akan memungkinkan untuk melakukan usaha perkebunan kelapa sawit lebih optimal sehingga pendapatan yang diterima lebih tinggi.

Tingkat kekosmopolitan tergolong rendah. Hal ini memberikan gambaran bahwa sebagian petani responden (62\%) tidak pernah atau jarang bepergian keluar desa untuk mengakses informasi mengenai pasar dan pencarian teknologi yang sesuai dengan lingkungan petani. Sikap petani yang menyerah pada nasib dan pasrah menyebabkan petani responden kurang berkeinginan mengembangkan usahatani menjadi lebih baik.

Petani dengan tingkat kekosmopolitan tinggi adalah ketua kelompok tani dan tokoh masyarakat, cenderung bepergian keluar desa untuk mencari informasi mengenai usahatani lada. Petani responden $(79 \%$ ) tidak pernah mendapatkan informasi mengenai usahatani lada melalui koran dan informasi dalam bentuk media tercetak $(62 \%)$. Hal ini berarti bahwa minat membaca dikalangan petani responden rendah yang diperkirakan berkaitan dengtan tingkat pendidikan formal yang di tempuh. Jangkauan wilayah pedesaan yang jauh dari perkotaan menghambat distribusi koran dan bahanbahan tercetak lainnya. Sebagian petani responden (98\%) pernah menonton siaran TV adalah tergolong tinggi. Petani responden lebih memanfaatkan televisi sebagai media hiburan. Sebagian besar petani responden tidak memperoleh informasi tentang usahatani lada selama tiga bulan terakhir pada saat penelitian dilakukan. Kebanyakan siaran yang di tonton oleh petani responden adalah acara berita, olah raga dan hiburan. Hal ini terkait dengan proporsi penanyangan acara televisi didominasi oleh acara hiburan dan olahraga, baik televisi swasta mapun televisi pemerintah.

Sebagian besar responden penelitian (71,11\%) memperoleh pendapatan yang bersumber dari pertanian. Pendapatan petani dari usahatani lada adalah di bawah Rp. 30.000 .000 per tahun. Hal ini berkaitan dengan keberagamana usaha yang dilakukan oleh petani, dimana sebagian besar petani responden memiliki sumber pendapatan hanya dari usahatani lada saja dengan luas lahan yang dimiliki sempit, sehingga pendapatan yang diperoleh dari usahatani lada rendah.Selain luas lahan yang sempit, rendahnya pendapatan responden disebabkan juga oleh pendidikan formalnya yang rendah. Berdasarkan hasil penelitian Purnaningsih dan Sugihen (2008), semakin tinggi tingkat penggunaan teknologi usahatani tanaman sayuran akan memberikan tingkat pendapatan yang tinggi juga kepada petani. 


\section{Persepsi Petani terhadap Diseminasi Teknologi Usahatani Lada}

Persepsi petani terhadap teknik diseminasi dibagi menjadi tiga kategori yaitu rendah, sedang dan tinggi. Persepsi petani terhadap teknik diseminasi teknologi usahatani lada meliputi temu lapang, demonstrasi plot, visitor plot dan pameran (Tabel 2).

Sebanyak $88,89 \%$ petani responden mempunyai persepsi petani terhadap teknik diseminasi temu lapang termasuk dalam kategori tinggi. Persepsi petani terhadap diseminasi teknologi lada melalui temu lapang tergolong tinggi, artinya bahwa persepsi petani terhadap temu lapang bersifat positif karena memberikan peluang bagi petani menyampaikan permasalahan yang dihadapi. Selain itu, pada saat temu lapang, petani berkesempatan melihat beberapa jenis teknologi usahatani lada, dapat bertemu dan bertanya kepada para peneliti dan penyuluh yang datang dari balai-balai penelitian, bertemu dengan pejabat daerah dan aparat desa dan tokoh-tokoh lainnya, sehingga ajang ini merupakan kesempatan istimewa dan kesempatan berharga bagi mereka untuk mendapatkan informasi baik yang berhubungan dengan tanaman lada maupun dengan permasalahan yang dihadapi petani di lapangan. Penyebaran informasi teknologi usahatani lada dalam temu lapang hanya disampaikan kepada pengurus kelompok, petani yang aktif, tokoh masyarakat dan aparat desa yang merupakan perwakilan dari desa sehingga informasi teknologi usahatani lada tidak sampai kepada semua petani.

Persepsi 55,5\% petani responden terhadap kegiatan diseminasi demonstrasi plot atau petak percontohan termasuk dalam kategori sedang dan lebih dari $40 \%$ petani responden lainnya mempunyai persepsi dalam kategori tinggi. Penyebaran inovasi teknologi menggunakan demonstrasi plot mudah terjangkau dan teknologi yang ada mudah dipahami. Hal ini disebabkan melalui plot demonstrasi, petani responden dapat melihat langsung hasil dari suatu inovasi yang diperkenalkan. Kepada petani responden ditunjukkan bukti-bukti nyata, sehingga cenderung cepat terdorong mencoba dan menerapkan inovasi yang diperkenalkan. Petani dan keluarga yang terlibat dalam pelaksanaan demonstrasi plot dapat belajar langsung dan dapat memberikan informasi kepada petani lain, sedangkan petani lain yang berada di sekitar kebun petani demplot dalam melihat langsung proses pelaksanaan teknologi yang diterapkan dan dapat bertanya langsung kepada petani kooperator tersbut, sehingga penyampaian teknologi dapat disebarkan melalui cara dan bahasa petani sendiri. Hal ini juga didukung dari letak kebun petani lada kooperator yang dijadikan

Tabel 2 Sebaran petani lada berdasarkan persepsi petani terhadap teknik diseminasi

\begin{tabular}{llcc}
\hline Teknik Diseminasi & Kategori & $\begin{array}{c}\text { Jumlah } \\
\text { (Orang) }\end{array}$ & $\begin{array}{c}\text { Persentase } \\
(\%)\end{array}$ \\
\hline Temu Lapang & Rendah & 4 & 4,44 \\
& Sedang & 6 & 6,67 \\
Demonstrasi plot & Tinggi & 80 & 88,89 \\
& Rendah & 0 & 0 \\
Visitor plot & Sedang & 50 & 55,60 \\
& Tinggi & 40 & 44,40 \\
& Rendah & 61 & 67,80 \\
Pameran & Sedang & 8 & 8,90 \\
& Tinggi & 21 & 23,30 \\
& Rendah & 0 & 0 \\
& Sedang & 55 & 61,10 \\
& Tinggi & 35 & 38,90 \\
\hline
\end{tabular}


sebagai tempat demplot adalah strategis dan mudah terjangkau. Petani memiliki kesibukan di masingmasing kebunnya, sehingga untuk sebagian petani dapat melihat peragaan beberapa teknologi yang ada di tempat petani kooperator hanya dapat dilakukan pada saat melewati kebun milik petani tersebut, sehingga, kondisi kurang tepat dan informasi yang didapatkan juga sedikit. Karena hal inilah menyebabkan petani tidak begitu banyak menerima informasi mengenai teknologi usahatani lada.

Persepsi lebih dari dua pertiga petani responden terhadap teknik visitor plot atau kebun percontohan termasuk dalam kategori rendah. Visitor Plot adalah petak percontohan teknologi dari hasil kegiatan pengkajian dan penelitian yang telah dilakukan oleh BPTP, yang diadakan di kebuh percobaan atau halaman/pekarangan kantor BPTP untuk memperagakan kepada pengguna dan stakeholder mengenai penerapan teknologi usahatani lada. Persepsi petani terhadap teknik diseminasi teknologi lada melalui visitor plot atau kebun percontohan masih tergolong rendah, karena hanya sebagian kecil petani responden pernah memperoleh informasi teknologi usahatani melalui petak percontohan. Hal ini disebabkan karena sebagian besar petani responden tidak pernah bepergian keluar desa sehingga tidak dapat juga mengunjungi petak percontohan tersebut. Selain itu, penyebab lainnya adalah letak kebun percontohan jauh sehingga kurang terjangkau karena letak petak percontohan di kebun percobaan Kantor Balai Pengkajian Teknologi Pertanian di Kota Pangkalpinang.

Persepsi lebih dari $60 \%$ petani responden terhadap pameran termasuk dalam kategori sedang. Persepsi petani terhadap diseminasi teknologi lada melalui pameran atau peragaan teknologi masih tergolong cukup besar pengaruhnya. Pelaksanaan kegiatan pameran dilaksanakan beberapa kali dalam setahun. Pameran mudah terjangkau dan memberikan banyak informasi kepada petani responden. Pameran yang pernah dilaksanakan oleh BPTP Kepulauan Bangka Belitung menampilkan visual benda dalam jumlah kecil seperti peragaan setek lada satu ruas, bibit-bibit lada yang sesuai anjuran, pestisida nabati, pengolahan hasil lada dalam bentuk kemasan. Pameran juga menyediakan informasi dalam bentuk tercetak folder, brosur, poster dan majalah mengenai budidaya lada anjuran.
Berdasarkan data tersebut dapat disimpulkan bahwa persepsi petani tentang kegiatan diseminasi teknologi terhadap tingkat adopsi usahatani lada tergolong baik. Persepsi petani terhadap temu lapang, demonstrasi plot dan pameran kategori sedang sampai tinggi karena memberikan informasi yang dibutuhkan oleh petani responden dan mudah terjangkau, sedangkan persepsi petani terhadap visitor plot kategori rendah disebabkan keberadaan tempat visitor plot yang jauh dari lokasi responden.

\section{Tingkat Adopsi Teknologi Usahatani Lada}

Adopsi teknologi usahatani lada dalam penelitian ini meliputi penggunaan varietas unggul, pemupukan, penggunaan bahan organik, penggunaan tiang panjat hidup, pengendalian hama dan penyakit menggunakan agensia hayati, dan penanganan panen dan pasca panen. Jumlah dan persentasi lada menurut penerapan usahatani lada yang baik dan benar di Bangka Belitung dapat dilihat pada Tabel 3. Sebagian besar petani responden $(63,33 \%)$ telah mengadopsi varietas unggul lada dalam kategori sedang. Hal ini menunjukkan bahwa inovasi teknologi penggunaan varietas unggul yang diperkenalkan sudah diterima baik oleh petani responden. Varietas unggul yang digunakan petani adalah varietas unggul yang sudah direkomendasikan untuk daerah Bangka Belitung. Varietas unggul yang rekomendasikan di Bangka Belitung adalah Petaling-1, Petaling-2, Natar-1, Natar-2, LDK-RS, Chunuk-RS dan Bengkayang-LU. Varietas unggul yang dominan di tanam pada lokasi penelitian adalah varietas Petaling-1, Petaling-2 dan LDK-RS. Hal ini dapat disimpulkan bahwa secara umum petani sudah mengetahui dan memahami keuntungan yang diperoleh dengan menggunakan varietas unggul, tetapi ada beberapa hal yang menjadi kendala dalam hal perbanyakan varietas unggul sesuai anjuran.

Penggunaan varietas unggul dalam usahatani masih tradisional menggunakan setek tujuh ruas, sedangkan perbanyakan varietas unggul yang dianjurkan adalah setek satu ruas. Manfaat perbanyakan varietas unggul dari setek satu ruas adalah untuk menghemat bibit lada, daya tumbuh setek satu ruas lebih baik dan dapat mengurangi penyebaran penyakit lada. hal ini didukung hasil penelitian Elly et al., (2014) mengatakan bahwa 
sebagian besar petani memiliki persepsi yang baik terhadap penggunaan benih padi unggul padi, petani mengetahui dan memahami keuntungan yang diperoleh dengan menggunakan benih padi unggul, namun masih terdapat beberapa hal yang menjadi kendala dalam menerapakan teknologi usahatani padi di Kecamatan Muara Pawan.

Tingkat adopsi oleh 53,33\% petani responden terhadap inovasi pemupukan termasuk dalam kategori sedang. Kategori sedang memberi arti bahwa aplikasi pemupukan yang baik dan benar dari segi jenis pupuk, dosis pupuk, cara pemupukan dan waktu pemupukan belum semuanya melaksanakan dengan tepat, hal inidipengaruhi oleh tingkat pengetahuan dan keterampilan petani yang rendah.

Tingkat adopsi $47,78 \%$ petani responden terhadap inovasi penggunaan bahan organik dalam usahatani lada termasuk dalam kategori sedang sampai tinggi. Penggunaan bahan organik yang digunakan petani responden sesuai anjuran di Bangka
Belitung adalah $0,5 \mathrm{~kg} /$ tanaman yang diaplikasikan bersamaan dengan pemupukan tanaman lada. Penggunaan bahan organik bagi tanaman lada sangat penting, karena kesuburan tanah tanah di Bangka Belitung pada umumnya rendah $(\mathrm{pH}$ rata-rata di bawah 5). Selain bahan organik yang berasal dari kotoran ternak, petani respoden telah memanfaatkan daun tanaman dari tiang panjat hidup sebagai kompos. Hasil penelitian Irma dan Mamik (2014) menjelaskan bahwa penilaian petani responden terhadap penggunaan bahan organik menunjukkan nilai skor 5, artinya seluruh petani dalam budidaya padi sawah dan pada musim tanam berikutnya bahan organik ini tetap digunakan. Petani menyadari bahwa menurunnya kesuburan lahan disebabkan oleh kurangnya penggunaan bahan organik.

Tingkat adopsi petani terhadap inovasi pengendalian hama dan penyakit menggunakan agensia hayati adalah termasuk kategori sedang, yang diadopsi oleh sebagian besar responden $(61,11 \%)$. Pengetahuan mengenai agensia hayati

Tabel 3 Jumlah dan persentasi petani lada menurut penerapan usahatani lada yang baik dan benar di Bangka Belitung (2015)

\begin{tabular}{llcc}
\hline Tingkat adopsi usahatani & Kategori & $\begin{array}{c}\text { Jumlah } \\
\text { (orang) }\end{array}$ & $\begin{array}{c}\text { Persentase } \\
\text { (\%) }\end{array}$ \\
\hline Varietas Unggul & Rendah & 4 & 4,44 \\
& Sedang & 57 & 63,33 \\
& Tinggi & 29 & 32,22 \\
Pemupukan & Rendah & 0 & 0 \\
& Sedang & 48 & 53,33 \\
Pengunaan Bahan Organik & Tinggi & 42 & 46,67 \\
& Rendah & 4 & 4,44 \\
& Sedang & 43 & 47,78 \\
Penanaman tiang panjat hidup & 43 & 47,78 \\
& Tinggi & 3 & 3,33 \\
& Rendah & 34 & 37,78 \\
& Sedang & 53 & 58,89 \\
Pengendalian hama penyakit & Tinggi & 0 & 0 \\
& Rendah & 46 & 51,11 \\
& Sedang & 44 & 48,89 \\
Panen dan pascapanen & Tinggi & 3 & 3,33 \\
& Rendah & 45 & 50,00 \\
& Sedang & 42 & 46,67 \\
\hline
\end{tabular}


atau pestisida nabati bagi petani merupakan suatu teknologi baru bagi mereka dan ditambah dengan pendidikan formal mereka yang tergolong rendah, menyebabkan penggunaan agensia hayati agak lambat dan masih rendah. Pengetahuan petani mengenai pengendalian hama dan penyakit dengan memperhatikan kelestarian lingkungan masih kurang walaupun sebagian petani sudah mengenal berbagai jenis musuh alami.

Tingkat adopsi petani terhadap inovasi penggunaan tiang panjat hidup adalah termasuk kategori tinggi. Sebagian besar petani responden $(58,89 \%)$ telah menggunakan tiang panjat hidup dalam usahatani ladanya. Pengetahuan petani terhadap teknologi penggunaan tiang panjat hidup sudah baik. Jenis tiang panjat hidup yang banyak digunakan untuk tanaman lada di Bangka Belitung adalah kayu Kapok, Dadap, Lamtoro dan Kalikiria atau Cebreng (Glyrisidia maculate). Petani sudah memahami manfaat penggunaan tiang panjat hidup seperti murah, memiliki masa panen yang lebih panjang hingga belasan tahun, mengurangi input tinggi bila menggunakan tiang panjat mati dan menjaga kelestarian lingkungan. Penanaman lada menggunakan tiang panjat mati memudahkan tanaman lada lebih mudah terserang hama dan penyakit.

Mayoritas petani responden $(96,67 \%)$ telah mengerti dan melaksanakan penanganan panen dan pascapanen sesuai anjuran dan dipengaruhi oleh kebiasaan bertanam lada yang sudah turun temurun sehingga penanganan panen dan pascapanen sudah sesuai dengan kriteria panen. Hasil wawancara dengan responden mengatakan bahwa proses penanganan pascapanen mulai dari perendaman, pencucian dan penjemuran sudah dimengerti oleh responden. Butir-butir lada (tanpa kulit) yang sudah bersih selanjutnya dijemur di lantai jemur dari semen atau di tepi jalan beraspal beralaskan tikar, plastik atau karung. Kualitas hasil masih belum optimal karena mutu produk masih rendah dan dikhawatirkan tercemar mikroorganisme. Hal ini dipengaruhi oleh rendahnya pengetahuan petani dan keterampilan petani dalam penanganan pascapanen. Hasil pengamatan dilapangan memperlihatkan bahwa bila pada saat perendaman lada yang dilakukan pada air yang tidak mengalir, menyebabkan warna lada menjadi kusam. Selain masalah air mengalir, kualitas lada juga dipengaruhi oleh penyimpanan, 70 sebagian besar responden tidak mempunyai tempat khusus untuk menyimpan hasil panen sehingga kerusakan akibat di makan tikus sering terjadi.

Berdasarkan data tersebut dapat disimpulkan bahwa tingkat adopsi usahatani oleh petani responden tergolong baik. Penerapan teknologi usahatani lada anjuran meliputi penggunaan varietas unggul, pemupukan, penggunaan bahan organik, pengendalian hama dan penyakit menggunakan agensia hayati, penggunaan tiang panjat hidup dan penanganan panen dan pascapanen masih belum maksimal hal ini disebabkan karena masih kurangnya pengetahuan dan keterampilan petani dalam menerapkan teknologi lada anjuran.

\section{Faktor-faktor yang Mempengaruhi Tingkat Adopsi Usahatani Lada}

\section{Karakteristik Petani}

Karakteristik petani merupakan gambaran awal sosok keseharian mereka yang diperlukan untuk memahami perilaku dalam menjalankan usahataninya. Karakteristik petani yang diteliti terdiri dari umur, pendidikan formal, jumlah tanggungan keluarga, lama berusahatani, luas lahan, kekosmopolitan dan pendapatan dapat dilihat pada Tabel 4.

Hasil uji regresi menunjukkan umur berpengaruh nyata dan positif terhadap tingkat adopsi teknologi usahatani lada. Umur merupakan suatu faktor yang mempengaruhi kemampuan fisik seseorang baik dalam berpikir maupun dalam bekerja. Umumnya petani yang lebih muda dan sehat memiliki kemampuan fisik yang lebih besar,

Tabel 4 Koefisien pengaruh karakteristik petani terhadap tingkat adopsi usahatani lada

\begin{tabular}{clr}
\hline No & Variabel & $\boldsymbol{\beta}$ \\
\hline 1 & Umur & $0.551^{*}$ \\
2 & Pendidikan Formal & 0.144 \\
3 & Jumlah tanggungan & -0.012 \\
& keluarga & \\
4 & Lama berusahatani & $-0,344^{*}$ \\
5 & Luas lahan & 0,090 \\
6 & Kekosmopolitan & 0,090 \\
7 & Pendapatan & $-0,250$ \\
\hline
\end{tabular}


bila dibandingkan dengan petani yang sudah lanjut usia. Semakin lanjut usia seseorang (di atas 50 tahun), kemampuannya akan berkurang, hal ini disebabkan oleh fungsi kerja otot semakin menurun, lamban untuk mengadopsi inovasi, dan cenderung hanya melaksanakan kegiatan-kegiatan yang sudah biasa di lakukannya. Padmowihardjo (1994) menyatakan bahwa umur bukan merupakan faktor psikologis, tetapi apa yang diakibatkan oleh umur adalah faktor psikologis. Faktor yang menentukan kemampuan seseorang berhubungan dengan umur adalah 1) mekanisme belajar dan kematangan otak, organ-organ sensual dan organ-organ tertentu dan 2) akumulasi pengalaman dan bentuk-bentuk proses belajar yang lain. Kisaran umur petani lada di lokasi penelitian adalah 20 hingga 70 tahun di mana mayoritas berada di usia 35-52 tahun. Menurut Mulyasa (2003), perkembangan kemampuan berpikir terjadi seiring dengan bertambahnya umur. Padmowihardjo (1994) mengungkapkan bahwa kemampuan umum untuk belajar berkembang secara gradual semenjak dilahirkan sampai saat kedewasaan. Asumsi ini dapat diketahui bahwa pada umur lebih lanjut orang akan belajar lebih cepat dan berhasil mempertahankan retensi dalam jumlah besar dari pada usia lebih muda, akan tetapi setelah mencapai umur tertentu, kemampuan belajar akan berkurang secara gradual dan terasa nyata setelah mencapai umur 55 ataupun 60 tahun, setelah itu penurunan akan lebih cepat lagi. Umur sangat menentukan kemampuan dan kemauan petani dalam menerima dan mau menerapkan teknologi usahatani padi sawah (Riyadi, 2003).

Lama usahatani berpengaruh nyata dan negatif terhadap tingkat adopsi teknologi usahatani lada. Hal ini berarti bahwa semakin lama petani dalam berusahatani lada maka tingkat adopsi usahatani lada semakin berkurang. Hal tersebut dipengaruhi oleh daya respon, tanggapan, penerimaan petani pada suatu informasi teknologi yang disampaikan kepada petani. Kebiasaan bertani lada yang sudah dijalankan petani menggunakan tata cara mereka bertani sebelumnya yakni teknologi tradisional sehingga petani yang telah lama berusahatani sulit untuk menerima perubahan cara bertani menggunakan teknologi baru. Dengan demikian harapan bahwa inovasi teknologi yang diadopsi petani dapat berlangsung secara berkesinambungan dan berkembang sesuai dengan keadaan dan kebutuhan, sulit terwujud. Di dukung hasil penelitian Roswida (2003) mengatakan bahwa semakin lama petani dalam berusahatani maka akan berpengaruh terhadap pengambilan keputusan apakah menerima atau menolak inovasi pertanian yang disampaikan.

\section{Persepsi Petani terhadap diseminasi teknologi}

Persepsi merupakan hasil penerapan pengetahuan seseorang terhadap situasi tertentu yang dapat dipahami dan memberikan arti terhadap dunia di sekitarnya. Persepsi petani terhadap diseminasi teknologi yang diteliti adalah temu lapang, demonstrasi plot, pameran dan visitor plot dapat dilihat pada Tabel 5.

Informasi teknologi hasil penelitian pertanian sangat dibutuhkan petani untuk mendukung kegiatan usaha tani. Pameran adalah usaha untuk memperlihatkan atau mempertunjukkan model, contoh, barang, gambar, poster, benda hidup dan sebagainya secara sistematik pada suatu tempat tertentu. Hasil uji regresi menunjukkan bahwa pameran berpengaruh nyata dan positif terhadap tingkat adopsi usahatani lada. Hal ini berarti bahwa pameran dapat mempengaruhi petani dalam usahataninya disebabkan karena menarik perhatian, menggugah hati, dan membangkitkan keinginan, serta menyakinkan pengguna dan pengunjung sehingga teknologi usahatani yang disampaikan dapat tercapai. Faktor lainnya adalah 1) pameran dapat mempengaruhi petani dalam mengadopsi usahatani lada anjuran karena frekuensi pelaksanaan pameran diadakan empat kali dalam setahun, baik pameran yang diadakan pemerintah maupun pihak swasta, dan 2) lokasi pameran terjangkau dan mudah bagi masyarakat pada umumnya dan petani lada khususnya untuk mendatanginya. Ketersediaan teknologi informasi dan komunikasi menjadi kunci penting untuk membangun petani

Tabel 5 Koefisien pengaruh teknik diseminasi terhadap tingkat adopsi usahatani lada

\begin{tabular}{clr}
\hline No & Variabel & \multicolumn{1}{c}{$\beta$} \\
\hline 1 & Temu Lapang & 0,025 \\
2 & Demonstrasi Plot & 0,152 \\
3 & Pameran & $* 0,261$ \\
4 & Visitor Plot & 0,008
\end{tabular}


dalam berkomunikasi secara efektif, karena selain mengatasi ruang dan waktu juga dapat memberdayakan seseorang dalam hal memberikan informasi pengetahuan dan kesempatan belajar bagi masyarakat serta memungkinkan seseorang menyatakan perhatian secara efektif berpartisipasi dalam proses pembuatan keputusan (Asian Development Bank, 2004).

\section{Kesimpulan}

Persepsi petani terhadap temu lapang, demonstrasi plot dan pameran kategori sedang sampai tinggi karena memberikan informasi yang dibutuhkan oleh petani responden dan mudah terjangkau, sedangkan persepsi petani terhadap visitor plot kategori rendah disebabkan keberadaan tempat visitor plot yang jauh dari lokasi responden.

Adopsi teknologi lada oleh petani responden tergolong baik. Penerapan teknologi usahatani lada anjuran penggunaan varietas unggul, pemupukan, penggunaan bahan organik, pengendalian hama dan penyakit menggunakan agensia hayati, penggunaan tiang panjat hidup dan penanganan panen dan pascapanen belum sepenuhnya sesuai anjuran.

Faktor-faktor karakteristik yang mempengaruhi petani dalam mengadopsi teknologi usahatani lada adalah umur dan lama usahatani, sedangkan faktor-faktor kegiatan diseminasi teknologi yang mempengaruhi tingkat adopsi teknologi usahatani lada adalah pameran.

\section{Daftar Pustaka}

Asian Development Bank. 2004. Building e-community Centres for Rural Development. Report of the Regional Workshop. Bali: Indonesia. Pp. 18-87

Aprionis. 2015. Produksi lada putih Bangka Belitung. [Internet] [diunduh 29 Oktober 2015]. Tersedia pada : http://babel.antaranews.com/ berita/17535/produksi-lada-putih-babel

Azwar. 2003. Sikap Manusia: Teori dan Pengukurannya (Lanjutan). Yogyakarta (ID): Pustaka Pelajar.

[BPTP] Balai Pengkajian Teknologi Pertanian Bangka Belitung. 2011. Budidaya Lada Ramah Lingkungan. Edisi Khusus Penas XIII.

[BPS] Badan Pusat Statistik. 2009. Statistik
Indonesia. [Internet] [diunduh 25 Maret 2015]. Tersedia pada: http://www.bps.go.id.

Elly H, Erlinda Y, Radian. 2014. Analisis Persepsi Petani dalam Penggunaan Benih Padi Unggul di Kecamatan Pawan Kabupaten Ketapang. Jurnal Social Economic of Agriculture 3(1) : 53-57

Hardjanto. 2003. Keragaan dan Pengembangan Usaha Kayu Rakyatdi Jawa .[disertasi]. Bogor (ID): Institut Pertanian Bogor.

Hermawan A, Irma AF, Hermanto. 2009. Lada Putih Bangka Belitung: Dari Kearifan Lokal sampai Subsidi. Prosiding Workshop Revitalisasi Lada. Pages 117-134. Pangkalpinang.

Irawati AFC, Wirasti CA, Herwan, Issukindarsyah, Panggabean MTL. 2009. Pengembangan Teknologi Budidaya Lada ramah lingkungan di Provinsi Bangka Belitung. Makalah Seminar Inovasi Pertanian Spesifik Lokasi di BBP2TP. Bogor

Irianto G. 2009. Konsep Rencana Aksi Revitalisasi Lada Putih "Muntok white Pepper" di Provinsi Kepulauan Bangka Belitung. Prosiding Workshop Revitalisasi Lada. Pangkalpinang.

Irma F, Mamik S. 2014. Persepsi dan Tingkat Adopsi Petani terhadap Inovasi Pengelolaan Tanaman Padi Terpadu Padi Sawah. Agriekonomika. Jurnal sosial ekonomi dan kebijakan pertanian 3(1): 1-10.

KelingerAN. 2006. Azas-azas Penelitian Behavioral. Yogyakarta (ID): Gadjah Mada University Press Mosher AT. 1987. Menggerakkan dan Membangun Pertanian. Jakarta (ID): CV. Yasaguna

Mulyana D. 2007. Ilmu komunikasi suatu Pengantar. Bandung (ID): PT. Remaja Rosdakarya.

Mulyasa E, 2003. Kurikulum Berbasis Kompetensi. Konsep Karakteristik, Implementasi dan Inovasi. Bandung: Remaja Rosdakarya Offset.

Nawawi H, Handari M. 2006. Instrumen Penelitian Bidang Sosial. Yogyakarta: UGM Press

Padmowihardjo S. 1994. Psikologi Belajar Mengajar. Jakarta: Universitas Terbuka.

Paryono TJ, Kartaatmaja S, Kushartanti E. (2001). Revitalisasi Penyuluhan Pertanian Pada Era Otonomi Daerah. Makalah Seminar Hasil Pengkajian BPTP Jawa Tengah.

Purnaningsih N, Ginting B. 2008. Manfaat Keterlibatan Petani dalam Pola Kemitraan Agribisnis Sayuran di Jawa Barat. Jurnal Penyuluhan 4(2) : 80-91 
Riyadi. 2003. Hubungan antara Hasil Pelatihan dengan Tingkat Penerapan Penerapan Padi Sawah Kalimantan Timur. [Tesis]. Bogor (ID): Institut Pertanian Bogor.

Rogers EM. 2003. Diffusion of Innovations. 5th Edition. New York: The Free Press.

Rogers EM, Shoemaker FF. 1971. Communication of Innovations: A Cross Cultural Approach. New York: The Free Press.

Roswida R, 2003. Tahapan Proses Keputusan Adopsi Inovasi Pengendalian Hama Penyakit Tanaman denganAgensia Hayati (Kasus Petani Sayur di Kecamatan Banuhampu dan Sungai Puar Kabupaten AgamSumatera Barat. [tesis]. Bogor (ID): Institut Pertanian Bogor.

Saragih B. 2001. Agribisnis. Paradigma Baru Pembangunan Ekonomi Berbasis Pertanian.

Jakarta (ID): Loji Grafika Griya Sarana

Sevilla CG, Ochave JA, Punsalam TG, Regala BP, Uriarte GG. 1993. Pengantar Metode Penelitian. Diterjemahkan oleh Tuwu A, Syah A. Jakarta: Universitas Indonesia Press. Terjemahan dari: An Introduction to Research Methods.

Soekartawi. 1988. Prinsip Dasar Komunikasi Pertanian. Jakarta (ID): Indonesia University Press.

Susi E, Evi M. 2010. Persepsi Petani terhadap Teknologi Pengolahan Pakan di Kecamatan Keinci Kanan Kabupaten Siak. Indonesian Journal of Agricultural Economics (IJAE) 2(1) : 171-183. 